\title{
Evaluasi Program Pelaksanaan Penilaian Akhir Tahun Berbasis Daring di SMA Takhasus Al-Qur'an Wonosobo
}

\author{
Khoirun Nisa1, Muhammad Mustahal'2, Ulil Fuadah ${ }^{3}$ \\ 1,2,3 Sekolah Tinggi Agama Islam An-Nawawi Purworejo \\ E-mail:irunicer@gmail.com
}

\begin{abstract}
Article Info
Abstract

Article History

Received: 2021-08-20

Revised: 2021-09-10

Published: 2021-10-08

Evaluation is a systematic activity undertaken to obtain and present information in order to make decisions. Evaluation can also be a measure of the extent to which educational goals are achieved. So that each program requires evaluation to determine the achievement of goals including online PAT held by SMA Takhasus Al-Qur'an

Keywords:

Evaluation;

CIPP Model;

PAT;

Online.

Wonosobo. There are various kinds of evaluation models, but in this study the researcher chose the CIPP model (Context, Input, Process, and Product). This model was chosen because it was felt that it made it easier to carry out evaluations. This type of research is a field research conducted at the Takhasus Al-Qur'an High School which is located on Jalan KH. Asy'ari No. 29 Kalibeber, Mojotengah, Wonosobo. Data collection methods used in this research are interview, observation, and documentation methods. There are two sources of data used in this study, namely primary data sources and secondary data sources. Primary data sources were obtained directly from Waka. Curriculum and some students of Takhasus Al-Qur'an High School Wonosobo. As for the secondary data, the authors obtained from the web, articles and others related to SMA Takhasus Al-Qur'an Wonosobo. After collecting the data, the next stage is the analysis stage which the writer will analyze with the descriptive analysis method. The results showed that the implementation of online PAT ran quite smoothly, but experienced some obstacles in the connection section.
\end{abstract}

\begin{tabular}{l}
\hline Artikel Info \\
\hline Sejarah Artikel \\
Diterima: $2021-08-20$ \\
Direvisi: $2021-09-10$ \\
Dipublikasi: $2021-10-08$
\end{tabular}

Kata kunci:

Evaluasi;

Model CIPP;

Penilaian Akhir Tahun; Daring.

\begin{abstract}
Abstrak
Evaluasi merupakan kegiatan sistematik yang dilakuakan untuk memperoleh dan menyajikan informasi guna mengambil keputusan. Evaluasi juga dapat menjadi tolak ukur sejauh mana tujuan pendidikan tercapai. Sehingga dalam setiap program memerlukan evaluasi guna mengetahui ketercapaian tujuan termasuk penilaian akhir tahun (PAT) berbasis daring yang diadakan oleh SMA Takhasus Al-Qur'an Wonosobo. Ada berbagai macam model evaluasi, namun dalam penelitian ini peneliti memilih model CIPP (Context, Input, Process,dan Product). Model ini dipilih karena dirasa memudahkan dalam melakuakn evaluasi. Jenis penelitian ini merupakan penelitian lapangan yang dilaksanakan di SMA Takhasus Al-Qur'an yang terletak di Jalan KH. Asy'ari No. 29 Kalibeber, Mojotengah, Wonosobo. Metode pengumpulan data yang dipakai dalam penelitian ini yaitu dengan metode wawancara, observasi, dan dokumentasi. Sumber data yang digunakan dalam penelitian ini ada dua yaitu sumber data primer dan sumber data sekunder. Sumber data primer diperoleh langsung dari Waka. Kurikulum dan beberapa siswa SMA Takhasus Al-Qur'an Wonosobo. Sedangkan untuk data sekunder penulis peroleh dari web, artikel dan lain sebagainya yang terkait dengan SMA Takhasus Al-Qur'an Wonosobo. Setelah pengumpulan data, maka tahap selanjutnya adalah tahap analisa yang akan penulis analisis dengan metode analisa deskriptif. Hasil penelitian menunjukkan bahwa pelaksanaan PAT berbasis daring berjalan cukup lancar hanya saja mengalami beberapa hambatan di bagian koneksi.
\end{abstract}

\section{PENDAHULUAN}

SMA Takhasus Al-Qur'an Wonosobo adalah salah satu SMA swasta terbaik dan favorit di Wonosobo. Selain itu SMA Takhasus merupakan SMA rujukan nasional. Sekolah juga sudah mengembangkan teknologi terbukti dengan adanya ruang dan ekstrakurikuler multimedia, SMA Takhasus Al-Qur'an Wonosobo adalah salah satu sekolah yang telah mengaplikasikan kegiatan berbasis daring dalam pelaksanaan kegiatan belajar mengajar dan evaluasi pembelajaran (PAT). Selain untuk mencegah persebaran virus corona pelaksanaan kegiatan pendidikan berbasis daring ternyata juga dimanfaatkan sebagai sarana untuk mengembangkan kemampuan bidang IPTEK bagi peserta didiknya, Berdasarkan fenomena yang ditemukan penulis pada saat observasi. tertarik untuk 
meneliti proses pelaksanaan penilaian akhir tahun berbasis daring di SMA Takhasus AlQur'an Wonosobo dikarenakan perbedaan situasi dan kondisi dari peserta didiknya baik secara geografis ataupun kondisi ekonominya. Sehingga dalam proses pelaksanaanya seringkali mengalami beberapa kendala seperti susah sinyal, kehilangan jawaban saat mengerjakan, kurangnya kesiapan server, banyaknya kegiatan di rumah, dan kadang terjadi mati listrik sehingga jawaban yang belum tersimpan hilang sehingga harus mengulang dari awal. Seperti kasus yang dialami oleh beberapa siswa kelas $\mathrm{X}$ MIPA 2 yang kehilangan jawaban karena mati listrik, susah sinyal, dan terdapat satu siswa kelas tersebut harus menempuh penilaian akhir tahun berbasis daring hanya dalam waktu tiga hari dikarenakan masalah ekonomi. Alhasil siswa tersebut tidak dapat menyelesaikan penilaian akhit tahun berbasis daring secara maksimal disebabkan terbatasnya waktu. Oleh karena itu dalam penelitian ini penulis berfokus pada proses pelaksanaan penilaian akhir tahun berbasis daring di SMA Takhasus Al-Quran Wonosobo.

\section{a) Evaluasi Program}

Evaluasi program termasuk pengukuran kinerja program, sumber biaya, aktivitas program, outcomes program, dan pengujian asumsi sementara yang berhubungan dengan tiga elemen ini. Satu kontribusi potensial penting dari evaluasi program adalah kegunaanya dalam pengambilan kebijakan guna mengubah sumber, aktivitas, atau tujuan program untuk meningkatkan kinerja program. Evaluasi merupakan salah satu kegiatan yang mengandung lebih banyak seni daripada ilmu pengetahuan. Dalam merencanakan evaluasi harus mampu mengidentifikasi program yang dilakukan. Evaluator harus mampu menyelaraskan kegiatan yang akan diprogramkan dengan biaya dan kondisi yang ada sehingga hasil evaluasi dapat membuahkan keuntungan dan dapat meningkatkan kualitas dari pelaksanaan program tersebut. (Suharsimi Arikunto \& Jabar, Cepi S.A., 2014).

b) Evaluasi Program Model CIPP

Evaluasi program model CIPP merupakan model yang paling banyak dikenal dan diterapkan oleh para evaluator. Oleh karena itu, uraian yang diberikan lebih panjang dibanding dengan model-model lainnya. Model ini bertitik pada pandangan bahwa keberhasilan progran pendidikan dipengaruhi oleh berbagai faktor, seperti: karakteristik peserta didik dan lingkungan, tujuan program dan peralatan yang digunakan, prosedur dan mekanisme pelaksanaan program itu sendiri. (Suharsimi Arikunto \& Jabar, Cepi S.A., 2014).

Evaluasi model ini bermaksud membandingkan kinerja dari berbagai dimensi program dengan sejumlah kriteria tertentu, untuk sampai pada deskripsi dan penilaian mengenai kekuatan dan kelemahan program yang dievaluasi. Inti evaluasi adalah untuk mengambil keputusan tentang kurikulum dalam arti luas. Suharsimi Arikunto dan Cepi menyatakan bahwa, evaluasi CIPP merupakan rangkaian dari evaluasi konteks, masukan, proses dan produk. (Suharsimi Arikunto \& Jabar, Cepi S.A., 2014). Untuk lebih rincinya adalah sebagai berikut:

\section{Context Evaluation}

Evaluasi konteks adalah upaya untuk menggambarkan dan merinci lingkungan, kebutuhan yang tidak terpenuhi, populasi dan sampel yang dilayani, dan tujuan proyek.

\section{Input Evaluation}

Evaluasi terhadap masukan merupakan evaluasi yang berkaitan dengan kemampua sekolah dalam menempatkan dan menyediakan petugas dan peserta yang handal untuk mensukseskan kegiatan program pembelajaran di sekolah.

3. Process Evaluation

Evaluasi proses dilaksanakan untuk mengukur sejauhmana program telah berjalan, dan bagaimana suasana dan proses program ini berjalan dengan sebaikbaiknya.

\section{Product Evaluation}

Evaluasi hasil dilaksanakan untuk mengukur hasil dari program yang telah dijalankan. Apakah hasil dari program yang telah dijalankan sudah sesuai dengan tujuan yang telah ditetapkan atau tidak.

Keempat komponen yang disebutkan dalam singkatan CIPP tersebut merupakan sasaran evaluasi, yang tidak lain adalah komponen dari proses sebuah program kegiatan. Dengan kata lain, model CIPP adalah model evaluasi yang memandang program yang dievaluasi sebagai sebuah sistem. (Suharsimi Arikunto \& Jabar, Cepi S.A., 2014).

c) Pengertian Penilaian Akhir Tahun Berbasis Daring

Penilaian akhir tahun daring berasal dari dua kata yaitu penilaian akhir tahun dan 
daring. Penilaian akhir tahun adalah penilaian yang dilakukan di setiap akhir tahun. Sedangkan daring berasal dari kata dalam jaringan. Artinya dalam pelaksanaannya membutuhkan koneksi internet. Jadi, penilaian akhir tahun berbasis daring adalah penilaian yang dilaksanakan setiap akhir tahun dengan memanfaatkan koneksi internet.

Penilaian akhir tahun daring atau yang sebelumnya dikenal dengan ulangan kenaikan kelas adalah penilaian yang dilakukan di semester genap dengan kompetensi dasar semua materi di semester genap yang dilakukan secara daring. Sebenarnya penilaian akhir tahun berbasis daring hampir sama dengan ujian sekolah ataupun ujian kenaikan kelas atau yang kini di kenal dengan istilah penilaian akhir tahun. Perbedaannya terdapat pada sistem pelaksanaannya yang dilaksanakan secara daring atau dalam jaringan.

\section{METODE PENELITIAN}

Penelitian ini termasuk dalam jenis penelitian kualitatif, juga termasuk dalam penelitian lapangan (field research) yaitu sebuah penelitian yang dilakukan dengan cara terjun langsung ke lokasi yang valid. Untuk memperoleh bahanbahan tersebut penulis melakukan pengamatan secara langsung pada obyek penelitian, yaitu penelitian mengenai evaluasi pelaksanaan program penilaian akhir tahun berbasis daring di SMA Takhasus Al-Qur'an Wonosobo.

Sifat penelitian ini adalah descriptif analitik yaitu suatu penelitian yang mengambil suatu masalah dan mendeskripsikan evaluasi pelaksanaan program penilaian akhir tahun berbasis daring di SMA Takhasus Al-Qur'an Wonosobo. Sesuai dengan jenis penelitian tersebut, maka penelitian ini membutuhkan sumber data, yaitu data Primer yang diperoleh dari interview secara langsug pada siswa, panitia penilaian akhir tahun, dan wakil kepala sekolah bidang kurikulum di sekolah tersebut. Sumber data sekunder dalam penelitian ini meliputi data tertulis, berupa web dan profil sekolah. Teknik pengumpulan data dengan cara Interview dan observasi.

\section{HASIL DAN PEMBAHASAN}

\section{A. Hasil Penelitian}

1) Pelaksaan Penilaian Akhir Tahun Berbasis Daring di SMA Takhasus Al-Qur'an Wonosobo

Pelaksaan penilaian akhir tahun berbasis daring di SMA Takhasus Al-Qur'an Wonosobo merupakan agenda perdana, karena pada pelaksanaan penilaian biasanya dilakukan secara langsung di gedung pendidikan sekolah tersebut. Pelaksanaan penilaian akhir tahun berbasis daring bermula dari adanya penyebaran virus corona yang semakin meluas dan meresahkan warga dunia. Hal itu mengakibatkan Menteri Pendidikan dan Kebudayaan, Nadhim Anwar Makarim mengeluarkan maklumat agar semua kegiatan pendidikan termasuk penilaian akhir tahun dilakukan secara daring guna memutus mata rantai penyebaran virus corona. Sehingga semua sekolah termasuk SMA Takhasus AlQur'an Wonosobo menyelenggarakan kegiatan penilaian akhir tahun secara daring. (Pujo Mulyono, 2020).

2) Kelebihan dan Kekurangan Penilaian Akhir Tahun Berbasis Daring

Pelaksanaan penilaian akhir tahun berbasis daring memiliki kelebihan menurut Bapak Pujo sebagai berikut: (Pujo Mulyono, 2020).

a. Siswa tidak harus datang ke sekolah.

b. Efesiensi waktu dan biaya.

c. Lebih aman.

d. Pengolahan data input dan output lebih valid.

Dalam setiap pelaksanaan program pastilah memiliki kelebihan dan juga kekurangan. Begitu pula dalam pelaksanaan penilaian akhir tahun secara daring memiliki kekurangan tersendiri. Adapun kekurangan penilaian akhir tahun berbasis daring menurut Bapak Pujo yaitu: (Pujo Mulyono, 2020).

3) Aplikasi

Pelaksanaan penilaian akhir tahun berbasis daring di SMA Takhasus Al-Qur'an Wonosobo menggunakan aplikasi CBT (Computer Based Test) seperti yang diterangkan Bapak Pujo berikut: "Aplikasi yang digunakan yaitu CBT karena memudahkan proses input dan output data namun kekuranganya yaitu server harus mengajari para guru dalm penggunaanya." Aplikasi yang digunakan yaitu CBT Aplikasi ini memiliki beberapa kelebihan dan kekurangan. Kelebihannya yaitu memudahkan keluar masuk data. Kekurangannya yaitu membutuhkan waktu untuk pelatihan para guru. (Pujo Mulyono, 2020).

4) Penanggung Jawab

Program penilaian akhir tahun berbasis daring di SMA Takhasus Al-Qur'an Wonosobo 
di bawah tanggung jawab Ibu Fatma Aeni, S.I.P., M.M, selaku kepala sekolah yang dibantu oleh Waka. Kurikulum dan panitia penilaian akhir tahun berbasis daring, serta guru mata pelajaran. (Pujo Mulyono, 2020).

5) Latar Belakang

Pelaksanaan penilaian akhir tahun daring bermula dari pesebaran virus corona yang makin luas. Kemudian dikeluarkanya keputusan untuk membatasi kerumunan, termasuk kegiatan belajar mengajar secara tatap muka. Keputusan tersebut dikeluarkan mentri pendidikan dan kebudayaan, Nadhim Anwar Makarim demi keaamanan bersama, Terkait latar belakang penilaian akhir tahun berbasis daring di SMA Takhasus al-Qur'an sendiri Bapak Pujo, selaku Waka. Kurikulum menyatakan bahwa: "Penilaian akhir tahun berbasis daring dilatarbelakangi oleh kondisi yang makin lama makin buruk, corona makin luas, penyesuaian perkembangan IPTEK, pemanfaatan teknologi CBT." (Pujo Mulyono, 2020), Jadi latar belakang penilaian akhir tahun berbasis daring di SMA Takhasus AlQur'an Wonosobo yaitu untuk mengembangkan kemampuan di bidang IPTEK, mengembangkan CBT dan meminimalisir penyebaran virus corona.

6) Kondisi Peserta Didik

SMA Takhasus Al-Qur'an Wonosobo adalah sebuah sekolah yang memiliki siswa yang berasal dari berbagai daerah. Perbedaan lertak geografis tersebut menimbulkan perbedaan kualitas koneksi internet. Dimana koneksi tersebut merupakan modal untuk dapat mengikuti penilaian akhir tahun berbasis daring. selain itu kondisi ekonomi mereka yang berbeda juga kadang menghambat kelancaran penilaian akhir tahun daring, dimana penilaian akhir tahun berbasis daring membutuhkan biaya yang cukup untuk pemenuhan kuota agar bisa masuk di aplikasi CBT. (Pujo Mulyono, 2020).

7) Dukungan Pemerintah dan Sekolah

Semakin meluasnya persebaran virus corona membuat semua aktivitas bersifat kerumunan dibatasi. Dampak corona tidak hanya mengganggu kegiatan di sektor ekonomi namun termasuk di ranah pendidikan. Seluruh kegiatan pendidikan di lakukan secara daring. Hal tersebut merupakan sebuah kebijakan dari Kemendikbud untuk memutus mata rantai persebaran virus tersebut. Bapak Pujo mengatakan bahwa: "Dari pemerintah sekolah mendapat subsidi internet sebesar 30 giga untuk pembelajaran dan 5 GB untuk umum." (Pujo Mulyono, 2020), Dari keterangan diatas diketahui SMA Takhasaus Al-Qur'an Wonosobo mendapatkan subsudi internet sebesar 30 GB untuk pembelajaran dan 5 GB untuk reguler.

8) Kesan Peserta Didik

Pelaksanaan penilaian akhir tahun berbasis daring ini memberikan kesan tersendiri bagi pesertanya. Ada yang merasa senang, ada yang merasa cukup dan adapula yang biasa saja. Mereka yang merasa cukup dan tidak ingin mengulangi lagi adalah yang mengalami beberapa hambatan.seperti yang dikisahkan oleh Putri: "Kesan saya selama daring ini ribet, sinyalnya susah, harus menyediakan paket data, dan semoga udah cukup sekali udah tidak mau ngulang lagi". (Putri Nur anggraini, 2020).

Berdasarkan cerita dari seorang siswa yang bernam Putri Nur Anggraini dari Purbalingga kelas XII MIPA 3, kesan yang dirasakan yaitu penilaian akhir tahun berbasis daring dirasa ribet karena susah sinyal, selain itu harus selalu menyediakan kuota agar dapat mengikut penilaian akhir tahun. Menurutnya penilaian akhir tahun berbasis daring ini cukup satu kali saja dan tidak mau lagi karena dirasa susah. Berbeda dengan cerita Dani berikut: "Kalau saya senang si, jadi nggak usah jauh- jauh ke sekolah karena bisa dilakukan dari rumah saya di Tegal. Lagian kalu didaerah saya kan sinyalnya juga bagus." (Ahmad Dani Akhyar, 2020), Dari cerita Dani ini menggambarkan bahwa dia tidak keberatan dengan penilaian akhir tahun berbasis daring tetapi merasa bahagia karenanya.

9) Pengaruh Penilaian Akhir Tahun Berbasis Daring

Pengaruh dari pelaksanaan penilaian akhir tahun berbasis daring cukup bagus seperti yang dikatakan oleh Pak Pujo berikut: " Pengaruh dari penilaian akhir tahun daring yaitu siswa dan guru jadi lebih memahami dan menguasai IPTEK dan juga CBT namun ketercapaian kurikulum masih kurang" Pengaruh penilaian akhir tahun berbasis daring menurut Pak Pujo yaitu penguasaan dibidang IPTEK terutama teknologi CBT, dan kurang tercapainya kurikulum. (Pujo Mulyono, 2020). 
10) Tata Tertib

Strategi yang digunakan agar penilaian akhir tahun berbasis daring lebih efektif yaitu dengan diadakanya tata tertib. Tata tertib penilaian akhir tahun daring SMA Takhasaus al-Qur'an adalah sebagai berikut: (Pujo Mulyono, 2020).

a. Siswa wajib bersiap 10 menit sebelum penilaian akhir tahun berbasis daring dimulai.

b. Pastikan koneksi bagus, baterai penuh.

c. Token dan user akan dibagikan melalui grup WA masing-masing kelas.

d. Penilaian akhir tahun berbasis daring dilaksanakan selam 14 hari.

e. Setiap hari terdapat 3 sesi dengan durasi tiap sesi 90 menit.

f. Tiap sesi untuk satu mata pelajaran.

Jika terjadi logout secara tiba-tiba, peserta diharapkan langsung menghubungi guru mapel atau wali kelas untuk meminta user agar bisa kembali login.

\section{B. Pembahasan}

Pelakasanaan PAT (Penilaian Akhir Tahun) daring di SMA Takahsus adalah evaluasi hasil belajar berbasis daring pertama kali. penilaian akhir tahun berbasis daring diadakan guna mematuhi peraturan pemerintah yang mengintruksikan untuk melakukan segala kegitan pendidikan secara daring. Hal ini dilakukan guna memutus mata rantai penyebaran virus corona. Di masa pandemi seperti ini penilaian akhir tahun berbasis daring merupaka cara terbaik untuk melakukan evaluasi terhadap peserta didik. Selain untuk keamanan bersama juga dapat meningkatkan kemampuan teknolgi bagi para siswa dan juga guru. Namun dalam pelaksanaann ya masih mengalami beberapa hambatan. Oleh karena itu perlu diadakanya evaluasi agar penilaian akhir tahun selanjutnya bisa lebih maksimal.

Dalam penelitian ini penulis menggunakan model evaluasi CIPP yang terdiri dari empat komponen yaitu Context (Konteks), Input (Masukan), Process (Proses), dan Product (Produk). Dari model evaluasi tersebut akan diketahui tentang pelaksanaan penilaian akhir tahun berbasis daring, kelebihan dan kekurangan, aplikasi yang digunakan latar belakang penilaian akhir tahun berbasis daring dan segala sesuatu yang berkaitan denganya. Lebih jelasnya adalah sebagai berikut:
1) Evaluasi Konteks (Context)

Evaluasi ini menjelaskan tentang perencanaan program harus mempertimbangkan beberapa hal sebelum dilaksanakan. Penilaian dari sisi konteks dalam penelitian ini digunakan untuk mengetahui kondisi geografis peserta didik, kebijakan pemerintah, kebijakan sekolah, serta kelebihan dan kekurangan dari penilaian akhir tahun berbasis daring. (Djuju Sudjana, 2006).

a. Latar Belakang Penilaian Akhir Tahun Berbasis Daring

Latar belakang penilaian akhir tahun berbasis daring di SMA Takhasus Al-Qur'an Wonosobo menurut keterangan Bapak Pujo di atas yaitu karena adanya virus corona yang terus meningkat dan terbatasnya kegiatan yang berkerumun seperti penilaian akhir tahun pada biasanya. Selain itu terdapat keinginan sekolah guna menyesuaikan perkembangan IPTEK yang semakin cepat. Pada zaman yang serba canggih ini penguasaan terhadap tekhnologi sangatlah penting, karena untuk saat ini dunia telah dikuasai oleh para ahli tekhnologi. Jika tidak dapat menyesuaikan maka akn tertinggal oleh peradaban zaman yang makin berkembang. Sehingga pihak yang tidak paham terhadap IPTEK akan tergilas oleh zaman. Oleh karena itu, penilaian akhir tahun berbasis daring merupakan sebuah peluang untuk mengembangkan kemampuan penguasaan IPTEK bagi siswa SMA Takhasaus. Apalagi mengingat mayoritas siswa sekolah ini adalah santri yang berdomisili di pondok pesantren, dimana penggunaan elektronik untuk mengembangkan kemampuan mereka dalam bidang tekhnologi terbatas. Tidak hanya kedua poin tersebut, latar belakang penilaian akhir tahun berbasis daring yaitu pemanfaatan tekhnologi CBT (Computer Best Test). Adanya program penilaian akhir tahun berbasis daring ini memberikan kesempatan untuk mengembangkan tekhlogi CBT. Teknologi ini merupakan satu salah aplikasi terbaik untuk melaksanakan ujian. Aplikasi ini biasanya digunakan untuk mengerjakan ujian nasional, sehingga dengan adanya penilaian akhir tahun berbasis daring memberikan kesempatan belajar lebih awal sebelum menghadipi ujian nasional. Dengan begitu saat sudah memasuki kelas 
dua belas dan melaksanakan ujian nasional daring menggunakan aplikasi ini sudah mahir.

b. Kondisi Geografis Peserta Didik

SMA Takhasus Al-Qur'an Wonosobo adalah salah satu sekolah dengan peserta didik yang cukup banyak dan berasal dari berbagai daerah. Para siswanya tidak hanya berasal dari daerah Wonosobo namun banyak yang berasal dari luar Wonosobo luar pulau. Peserta didiknya berasal hampir dari seluruh penjuru nusantara, bahkan luar negeri. Meskipun kebanyakan berasal dari pulau jawa namun tidak sedikit yang berasal dari luar jawa seperti Riau, Jambi, NTT, NTB, Papua, Bali, Kalimantan, Sulawesi, dan masih banyak lagi. Perbedaan wilayah tersebut menyebabkan perbedaan kualitas sinyal para siswa. Tidak semua wilayah memiliki kualitas sinyal yang baik. Beberapa daerah hanya memiliki sinyal kartu tertentu bahkan semua jenis sinyal sulit didapat. Seperti yang diceritan Khayatul Fauziah seorang siswi kelas XI MIPA 2 yang rumahnya berada di daerah yang jauh dari keramaian kota.

"Kalau di daerah saya itu karena lokasinya agak di dalam sehingga agak terganggu dengan jaringan. Di daerah saya yang sinyalnya bagus cuma Telkomsel karena di desa saya ada tower telkomsel. Selain itu cukup susah harus nyantel di jendela terus itupun masih tergantung dengan HP yang digunakan. Jika HP tidak mendukung pasti akan beda cerita." (Khayatul Fauziyah, 2020).

Kualitas sinyal sangat mempengaruhi kelancaran pelaksanaan penilaian akhir tahun berbasis daring. Tanpa sinyal yang baik proses penilaian akhir tahun berbasis daring akan sangat terpengaruh. Kareana jika sinyal hilang maka secara otomatis peserta penilaian akhir tahun akan logout. Dan harus mengulang login. Namun belum berhenti disitu karena setelah login semua jawaban akan hilang. Sehingga harus mengulang mengerjakan penilaian akhir tahun berbasis daring dari awal lagi. Seperti peristiwa yang terjadi pada salah satu siswi kelas XI MIPA 2 yaitu Khayatul Fauziyah asal Wonosobo. Daerah asalnya merupakan daerah yang cukup jauh dari pusat kota Wonosobo. Untuk dapat mencapai kota membutuhkan waktu sekitar satu jam. Disana kualitas sinyal kurang. Bahkan untuk mendapat sinyal yang bagus harus duduk di jendela atau bahkan keluar dari desa. Sinyal yang cukup bagus di daerah tersebut adalah sinyal telkomsel dikarenakan terdapat tower di desa tersebut, itupun jika HP yang digunakan kurang mendukung sinyalnya jarang bisa 4G, biasanya hanya $\mathrm{H}^{+}$Akan tetapi harga kuota telkomsel yang mahal dan harus memiliki stok yang banyak menjadi keluhanya. Mengingat ekonomi di pedesaan tidak terlalu baik apalagi di masa pandemi. Sehingga jika kuota menipis dia mulai hawatir akan kehabisan kuota. Jika kuota sudah minim akan mempengaruhi kualitas jaringan miliknya.

Selain itu, cuaca juga mempengaruhi kualitas sinyal seperti yang dikisahkan Fikhri sebagai berikut: "saya pernah waktu hujan itu sinyalnya hilang karena hujan angin. Saya langsung menghubungi wali kelas dan login kembali. Tapi jawaban hilang semua dan harus ngulang dari awal.Untung saja waktunya cukup untuk menyelesaikan." (Fikhri Sangadah, 2020), Jika terjadi hujan dan angin kencang dapat merusak koneksi seperti yang dialami oleh salah satu siswi SMA Takhasus Al-Qur'an Wonosobo bernama Fikhri Sangadah kelas XI MIPA 2. Disaat cuaca cerah dan tidak hujan penilaian akhir tahun berlangsung lancar namun ketika hujan tiba sinyal hilang dan koneksi terputus. Untung kejadian tersebut berlangsung tidak lama. Setelah itu, diapun langsung menghubungi gurunya dan meminta user untuk bisa login kembali. Namun jawaban yang telah dia hasilkan sebelumnya telah hilang, sehingga dia harus mengulanya dari awal.

Sesuai dengan hasil penelitian kebutuhan yang belum tercapai pada pelaksanaan penilaian akhir tahun berbasis daring ini yaitu. Sinyal yang baik untuk seluruh siswa. Karena kunci sukses dari pelaksanaann penilaian akhir tahun berbasis daring ini yaitu sinyal yang baik namun pada kenyataanya ada beberapa siswa yang masih terkendala sinyal baik disebabkan oleh kondisi geografis dan cuaca yang kurang mendukung.

c. Dukungan Pemerintah dan Sekolah

Program penilaian akhir tahun berbasis daring merupakan agenda dari Kemendikbud yang diperuntukan bagi 
semua sekolah guna memutus mata rantai persebaran virus corona. Sehingga pemerintahpun mendukung adanya penilaian akhir tahun berbasis daring ini. Di SMA Takhasus mendapatkan bantuan berupa subsidi internet sebesar $30 \mathrm{~GB}$ untuk pembelajaran dan $5 \mathrm{~GB}$ untuk umum. Adanya subsidi dari pemerintah tesebut diharapkan dapat membantu meringankan beban biaya selama pelaksanaan kegiatan pendidikan berbasis daring termasuk penilaian akhir tahun, sedangkan dari sekolah sendiri membuat kebijakan yaitu memberi diskon dalam pembayaran SPP tidak full. Pembayaran SPP biasanya sampai Juni untuk era pandemi ini pembayaran SPP sampai bulan Mei untuk meringankan peserta didik. Dengan kebijakan tersebut diharapkan biaya SPP bisa dialihkan untuk membeli kuota selama kegiatan daring. Selain dari segi biaya SMA Takhasus memberikan kebijakan berupa ujian susulan bagi yang berhalangan mengikuti penilaian akhir tahun berbasis daring sesuai jadwal yang telah ditentukan.

2) Evaluasi Masukan (input)

Evaluasi Input (masukan) adalah program menyediakan data untuk menentukan bagaiman penggunaan sumber-sumber yang dapat digunakan untuk mencapai tujuan program penilaian akhir tahun berbasis daring. Masukan-masukan yang ada akan diproses dan digunakan untuk dijadikan sebagai dasar pencapaian tujuan program. (Djuju Sudjana, 2006). Masukan-masukan yang ada digunakan untuk mengetahui kondisi ekonomi, aplikasi yang digunakan, sarana pendukung, dan serven dalam pelaksanaan penilaian akhir tahun berbasis daring.

\section{a. Kondisi Ekonomi Siswa}

Adapula salah satu siswa yang mengalami kesulitan karena belum memiliki HP android untuk mengikuti penilaian akhir tahun berbasis daring sampai $\mathrm{H}-3$ selesai penilaian akhir tahun. Khusnul Khotimah mengatakan bahwa:

"Saya bisa mengikuti penilaian akhir tahun berbasis daring di hari 3 terakhir dan saya diberi waktu 3 hari untuk menyelesaikan seluruh mata pelajaran. Untung saya bisa mengejarnya berkat dukungan dan semangat dari teman-teman saya. Hal itu karena HP saya kurang mendukung pelaksanaan PAT. Sehingga saya harus membeli HP baru dan baru bisa mengikuti PAT di 3 hari terakhir. Untung saya masih mendapat peringkat ke-7. Walaupun sebenarnya pada semester sebelumnya masih bisa peringkat satu. Namun itupun saya sudah syukur Alhamdulillah masih bisa masuk sepuluh besar." (Khusnul Khotimah, 2020).

Dari pengalaman salah satu siswi kelas XI MIPA 2 yang bernama Khusnul Khotimah, dia baru dapat mengikuti penilaian akhir tahun di 3 hari terakhir dikarenakan fasilitas yang kurang mendukung. Kondisi ekonomi dari para siswa juga mempengaruhi kelancaran PAT daring. Dalam pelaksanaan penilaian akhir tahun berbasis daring ini membutuhkan stok kuota yang banyak dan HP android minimal versi 5 . Dari pengalaman tersebut memberikan informasi bahwa kondisi ekonomi dari wali murid juga menjadi salah satu kendala dalam pelakasanaan penilaian akhir tahun berbasis daring. Karena untuk mendapatkan fasilitas berupa HP android dan persediaan kuota yang cukup bukanlah hal yang mudah untuk wali murid yang besik ekonominya menengah ke bawah. Apalagi di masa pandemi ini sangat sulit untuk mendapatkan pekerjaan. Banyak terjadi PHK dimana-mana, perusahaan bangkrut, harga kebutuhan yang melambung tinggi, namun tidak diimbangi dengan penghasilan yang memadai. Dengan begitu dalam kasus ini penilaian akhir tahun berbasis daring merupakan salah satu beban tersendiri bagi orang tua siswa yang mengalami krisis ekonomi. Sedangkan penilaian akhir tahun berbasis daring adalah satu tuntutan agar putra-pputri mereka dapat mengikuti kelas tingkat selanjutnya. Padahal seharusnya pandemi ini mereka diringankan bukanya dibebani.

b. Aplikasi yang digunakan

Aplikasi yang digunakan dalam pelaksanaan penilaian akhir tahun berbasis daring adalah aplikasi CBT (Computer Based Test). Aplikasi ini dipilih untuk digunakan dalam pelaksanaan penilaian akhir tahun berbasis daring karena aplikasi ini memudahkan dalam proses input dan output data. Nilai dari pelaksanaan penilaian akhir tahun berbasis daring akan langsung muncul dan masuk dalam data. Sehingga para guru tidak perlu untuk 
mengoreksi hasil ujiann para siswanya. Selain itu, hasil ujian lebih objektif. Dalam penilaian ini tidak ada katrol nilai. Nilai otomatis muncul setelah selesai mengerjakan. Namun aplikasi ini memiliki kekurangan yaitu untuk menggunakanya server harus mengajari para guru agar dapat memandu para siswanya mengikuti penilaian akhir tahun berbasis daring. sebelum di adakan penilaian akhir tahun para guru diberikan pelatihan untuk mengoprasikan aplikasi ini baik untuk memasukan ataupun mengawasi pelakasanaan penilaian akhir tahun berbasis daring, pelatihan terhadap para guru ini membutuhkan waktu yang tidak sedikit, apalagi untuk guru yang sudah tidak muda lagi. Tidak semua guru dapat langsung menyesuaikan penggunaan aplikasi ini. Kemapuan mereka dalam menguasai tekhnologi juga berbeda sehingga server harus bersabar. Bagi guru yang kurang paham dalam bidang tekhnologi terlebih guru yang sudah tidak muda lagi sudah terbiasa dengan ujian yang bersifat langsung menggunakan kertas merasa penilaian akhir tahun berbasis daring ini cukup sulit. Apalagi penilaian akhir tahun berbasis daring baru terjadi sekali di sekolah ini. Wajar saja jika masih terjadi kesalahan dan kesulitan dalam pengggunaaan aplikasi ini.

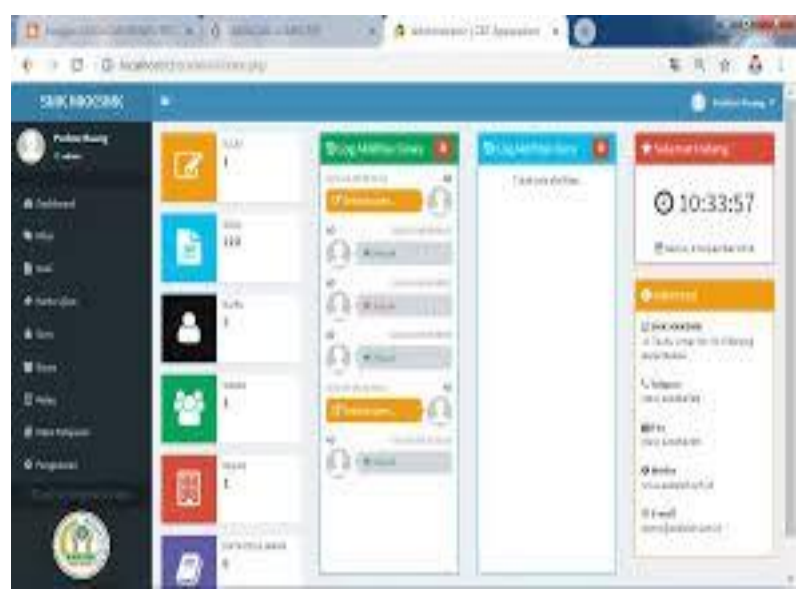

Gambar 1. Aplikasi CBT

\section{c. Sarana Pendukung dan Server}

Program penilaian akhir tahun berbasis daring ini membutuhkan sarana yang mendukung, seperti komputer untuk server, jenset untuk cadangan jika terjadi mati listrik dan wifi yang bagus. Di SMA Takhasus ini menyediakan jenset untuk mengantisipasi mati listrik. Penilaian akhir tahun berebasis daring ini di setir oleh seorang serven yang merupakan salah satu personil dari bagian kurikulum, dalam pelaksanaan penilaian akhir tahun berbasis daring ini tugas serven yaitu bekerja sama dengan para guru dan wali kelas untuk mengawasi berjalanya penilaian akhir tahun dan menyebarkan user dan token bagi peserta penilaian akhir tahun berbasis daring agar bisa login. User diberikan melalui grup WA kelas masing-masing. Peran dari serven sangatlah penting jika server lengah maka saat terjadi logout dan guru tidak bisa dihubungi, maka dialah nyang bertugas memberi user.

d. Kelebihan dan Kekurangan Penilaian Akhir Tahun Berbasis Daring

Pelaksanaan penilaian akhir tahun berbasis daring ini memeliki beberapa kelebihan yaitu:

1) Siswa tidak harus datang ke sekolah

Penilaian akhir tahun daring ini sebenarnya memberikan kemudahan bagi siswa dalam musi pandemi ini. Seperti yang kita ketahui selama pandemi ini interaksi dengan banyak orang sangat dibatasi guna memutus rantai persebaran virus corona yang semakin meluas dan mematikan. Sehingga dengan adanya penilaian akhir tahun daring ini peserta penilaian akhir tahun tidak perlu datang ke sekolah. Cukup mengikuti penilaian akhir tahun secara daring dari rumah masingmasing.

2) Efesiensi waktu dan biaya

Pelaksanaan penilaian akhir tahun berbasis daring ini sebenarnya menghemat waktu dan biaya. Karena peserta didik dan guru tidak harus datang ke sekolah. Pelaksanaan penilaian akhir tahun berbasis daring dapat dilakukan dari rumah masingmasing. Sehingga bisa menghemat biaya dan waktu.

3) Lebih aman

Pelaksanaan penilaian akhir tahun secara daring yang bisa dijangkau dari rumah masing-masing tanpa harus datang ke lokasi sekolah membuat peserta penilaian akhir tahun lebih aman di masa pandemi ini. Mengingat virus cirona yang kian meruas dan membahayakan. penilaian akhir tahun 
berbasis daring memberikan jaminan keamanan tersendiri bagi pelaksananya.

4) Pengolahan data input dan output lebih valid

Penilaian akhir tahun yang dilaksanakan secara online diakui dapat membantu dalam pengolahan data. Dalam proses pelaksanaanya setiap data langsung masuk ke server sehingga pengolahan data lebih mudah dan lebih valid, dalam setiap pelaksanaan program pastilah memiliki kelebihan dan juga kekurangan. Begitu juga dalam pelaksanaan penilaian akhir tahun secara daring memiliki kekurangan tersendiri. Adapun kekurangan penilaian akhir tahun berbasis daring yaitu:

5) Situasi dan kondisi peserta didik yang berbeda-beda

Situasi dan kondisi peserta didik yang berbeda baik secara geografis dan ekonomi sangat menentukan koneksi. Karena koneksi dalam pelaksanaan program penilaian akhir tahun berbasis daring merupakan kunci yang paling utama. Secara geografis letak tempat tinggal peserta didik berbeda-beda. Ada yang berada di kota, di desa dan ada yang bertempat di tempat yang agak pelosok. Selain terkendala sinyal peserta didik terkendala oleh kondisi ekonomi. Karena dalam pelaksanaan penilaian akhir tahun berbasis daring ini membutuhkan kuota banyak dan tidak boleh samapi kehabisan.

6) HP tergantung spesifikasinya

Untuk dapat mengikuti penilaian akhir tahun berbasis daring ini harus didukung dengan fasilitas yang memadai karena sangat mempengaruhi koneksi. Untuk dapat mengikuti penilaian akhir tahun berbasis daring dibutuhkan HP minimal android tipe 5 . Sedangkan tidak semua peserta didik memilikinya. Sehingga mau tidak mau semua peserta didik harus bisa menyediakan HP android tipe 5 baik itu dengan cara membeli atau meminjam dari kerabat untuk dapat mengikuti penilaian akhir tahun berbasis.

3) Evaluasi Proses (Process)

Evaluasi proses lebih menjelaskan mengenai pelaksanaan program. Evaluasi proses mendeteksi dan memprediksi hambatan dalam pelaksanaan program. (Djuju Sudjana, 2006). Evaluasi proses pada pelaksanaan penilaian akhir tahun berbasis daring dari sisi kesan peserta didik dan penanggung jawab.

a. Strategi Penilaian Akhir Tahun Berbasis Daring

Strategi sangatlah perlu diadakan guna meminimalisir sebuah kegagalan, begitupun dalam pelaksanaan penilaian akhir tahun berbasis daring sangatlah diperlukan adanya strategi. Strategi yang digunakan dalam penilaian akhir tahun berbasis daring yaitu dibuatnya tata tertip, pelatihan guru, dan pengawasan murid oleh guru. Tata tertib digunakan sebagai salah satu strategi dalam pelaksanaan penilaian akhir tahun berbasis daring guna menertibkan siswa. Dengan adanya tata tertib pelakasanaan penilaian akhir tahun berbasis daring lebih tertata dan tertib.

Pelatihan guru ini merupakan strategi untuk memberikan pemahaman guru dalam penggunaan aplikasi CBT. Baik untuk membuat soal ataupun untuk mendapatkan informasi nilai siswa. Sedangkan pengawasan guru terhadap siswa ditujukan agar apabila terjadi logout siswa langsung bisa meminta user sehingga langsung bisa melanjutkan pekerjaanya untuk mengerjakan penilaian akhir tahun .

b. Kesan Peserta Didik

Pelaksanaan penilaian akhir tahun berbasis daring ini memberikan kesan tersendiri bagi pesertanya. Ada yang merasa senang, ada yang merasa cukup dan adapula yang biasa saja. Mereka yang merasa cukup dan tidak ingin mengulangi lagi adalah yang mengalami beberapa hambatan.seperti yang dikisahkan oleh Putri: "Kesan saya selama daring ini ribet, sinyalnya susah,harus nyetok paketan terus, dan semoga udah cukup sekali udah tidak mau ngulang lagi" (Putri Nur anggraini, 2020).

Berdasarkan cerita dari seorang siswa yang bernama Putri Nur Anggraini dari Purbalingga kelas XII MIPA 3, kesan yang dirasakan yaitu penilaian akhir tahun berbasis daring dirasa ribet karena susah sinyal, selain itu harus selalu nyetok kuota agar bisa ikut penilaian akhir tahun. Menurutnya penilaian akhir tahun berbasis daring ini cukup satu kali saja dan tidak mau lagi karena dirasa susah. Berbeda 
dengan cerita Dani berikut: "Kalau saya seneng si, jadi nggak usah jauh- jauh ke sekolah karena bisa dilakukan dari ruamah saya di Tegal. Lagian kalu didaerah saya kan sinyalnya juga bagus." (Ahmad Dani Akhyar, 2020).

Adapula yang merasa bahagia melakukan penilaian akhir tahun berbasis daring dengan alasan mendapat bonus liburan di rumah lebih lama. Jika penilaian akhir tahun diklakukan secara manual liburan tidak akan sepanjang saat dilaksanakan secra daring. apalgi kebanyakan siswa SMA Takhasus merupakan santri yang menetap di pondok pesantren dimana untuk bisa pulang kampung sangat terbatas. Wajar saja jika merasa senang mendapat waktu libur lebih panjang. Apalagi untuk siswa dari luar daerah seperti Sumatera yang belum tentu dapat pulang kampung tiap liburan. Bisa satu tahun sekali, dua tahun sekali atau bahkan belum pernah pulang sama sekali selama berada di pesantren. Dengan adanya penilaian akhir tahun berbasis daring hampir semua siswa pulang ke kampung halaman masingmasing. Dari kesan beberapa siswa tersebut dapat disimpulkan semakin baik jaringan semakin baik kesan peserta penilaian akhir tahun.

c. Penanggung Jawab

Pelaksanaan penilaian akhir tahun berbasis daring ini di bawah tanggung jawab kepala SMA Takhasus Al-Qur'an Wonosobo yaitu, Ibu Fatma Aeni, S.I.P., M.M. Sebagai seorang kepala sekolah maka segala program yang diadakan oleh sekolah berada dibawah tanggung jawabnya.

4) Evaluasi Produk (Produk)

Evaluasi ini dilihat dari produk dari program yang dijalankan. Keberhasilan tersebut dapat dilihat dengan menggunakan satu indikator yaitu pengaruh program. Pengaruh dari kegiatan penilaian akhir tahun berbasis daring cukup baik, dengan diadakan penilaian akhir tahun secara daring hasil data yang diperoleh menjadi lebih valid dan obyektif. Seperti yang sudah dibahas diawal bahwa, dalam pelaksanaan penilaian akhir tahun ini data yang di dapat berupa nilai lebih valid dan objektif. Nilai langsung muncul setelah mengerjakan penilaian akhir tahun. Sehingga guru tidak berkesempatan untuk memberikan katrolan nilai. Nilai yang dihasilkan merupakan nilai murni. Selain itu, pengaruhnya sesuai dengan latar belakang penilaian akhir tahun berbasis daring yang bertujuan untuk mengembangkan kemampuan peserta didik di bidang IPTEK dan mengembangkan tekhnologi CBT.

Sebenarnya perkembangan kemampuan di bidang IPTEK dan tekhnologi CBT tidak hanya hanya para siswanya, namun para guru juga merasakan. Dengan adanya penilaian akhir tahun daring peserta didik dan guru lebih menguasai IPTEK dan tekhnologi CBT. Namun penilaian akhir tahun berbasis daring ini juga memiliki efek yang kurang baik yaitu kurang tercapainya kurikulum. Karena pada hakikatnya kompetensi dasar yang dinilai pada pelaksanaan penilaian akhir tahun tidak hanya dalam ranah koginitif saja akan tetapi ranah juga ranah psikomotorik dan afektif. Ranah afektif seperti kejujuran, sikap, dan lain-lain. Penilaian afektif tentu saja akan sulit dicapai dengan penilaian secara daring.

\section{SIMPULAN DAN SARAN}

\section{A. Simpulan}

Berdasarkan hasil penelitian yang telah dilakukan dapat ditarik kesimpulan bahwa, pelaksanaan penilaian akhir tahun berbasis daring di SMA Takhasus Al-Qur'an berjalan cukup lancar dilihat dari analisis evaluasi model CIPP sebagai berikur: 1). Evaluasi Conteks, hasil evaluasi konteks berdasarkan penelitian sudah cukup baik dilihat dari kebijakan pemerintah dan sekolah, serta kondisi geografis siswa. 2). Evaluasi Input, evaluasi input (masukan) dilihat dari server, sarana, dan aplikasi yang digunakan cukup lancar. Karena server dan aplikasi ini cukup membantu terlaksananya PAT daring. 3). Evaluasi Process, evaluasi proses penilaian akhir tahun cukup lacar dapat dilihat dari adanya strategi penilaian akhir tahun yang berfungsi untuk menertibkan peserta penilaian akhir tahun berbasis daring. 4). Evaluasi Product, evaluasi program secara garis besar sudah lumayan baik. Walupun masih kurang dalam pencapaian kurikulum.

\section{B. Saran}

Adapun saran yang dapat disampaikan yakni untuk peneliti selanjutnya untuk mengembangkan penelitian ini.

\section{DAFTAR RUJUKAN}

Arikunto, Suharsimi \& Jabar, Cepi S.A. 2014. Evaluasi Program Pendidikan: Pedoman 
Teoretis, Praktis Bagi Mahasiswa dan Praktisi Pendidikan. Jakarta: Bumi Aksara.

As - Shofa, Burhan. 2004. Metode Penelitian Hukum. Jakarta: PT Rineka Cipta.

Depdikbud RI. 2011. Kamus Besar Bahasa Indonesia. Jakarta: Balai Pustaka.

Hayati, Mardiyah. 2009. Desain Pembelajaran. Pekanbaru: Yayasan Pustaka Riau.

Moleong, Lexy J. 2012. Metode Penelitian Kualitataif. Bandung: PT Remaja Rosda Karya.

Purwanto. 2013. Evaluasi Hasil Belajar. Yogyakarta: Pustaka Pelajar.
Shodikin, Ali dkk. 2020. Pembelajaran Daring di Tengah Wabah Covid-19. Raudah. Vol. 06, No. 02

Sudjana, Djuju. 2006. Evaluasi Pendidikan Luar Sekolah. Bandung: PT Remaja Rosdakarya.

Sugiyono. 2018. Metode Kualitatif, Kuantitatif, dan $R \& D$. Bandung: ALFABETA.

Surakhman, Winarno. 2004. Pengantar Penelitian Dasar Metode dan Teknik. Bandung: Tarsito.

Surat Edaran Nomor 36962 pada tanggal 17 Maret 2020. 